\title{
Oil Price and Exchange Rate Volatility in Nigeria
}

\author{
Oluwatomisin M. Ogundipe ${ }^{\mathrm{a}}$, Paul Ojeaga ${ }^{\mathrm{a}}$, Adeyemi A. Ogundipe ${ }^{\mathrm{a}}$ \\ ${ }^{a}$ Department of Economics and Development Studies Covenant University, Ota Nigeria
}

\begin{abstract}
Oil as the mainstay of the Nigerian economy, accounts for over 95 percent of its foreign earnings and about 83 percent of its budgetary allocation, to this end, changes in oil prices has implications for the Nigerian economy and, in particular, exchange rate movements. The latter is mostly important due to the double dilemma of being an oil exporting and oil-importing country, a situation that emerged in the last decade. The study examined the effects of oil price, external reserves and interest rate on exchange rate volatility in Nigeria using annual data covering the period 1970 to 2011. The long run relationship among the variables was determined using the Johansen Co-integration technique while the vector correction mechanism was used to examine the speed of adjustment of the variables from the short run dynamics to the long run equilibrium. It was observed that a proportionate change in oil price leads to a more than proportionate change in exchange rate volatility in Nigeria; which implies that exchange rate is susceptible to changes in oil price. The study therefore recommend that the Nigeria government should diversify from the oil sector to other sectors of the economy hereby dwindling the impact of crude oil as the mainstay of the economy and overcome the effect of incessant changes in crude oil prices which often culminate into macroeconomic instability.
\end{abstract}

Keywords: Oil Price, Exchange rate volatility, Johansen Co-integration, Vector Error Correction Model Jel Classification: O24 C22 F41

\section{Introduction}

There are various evidences, particularly over the post-Breton woods era, pointing to the vital role of oil price fluctuations in the determination of the path of the exchange rate (Adeniyi et al., 2004). According to Krugman (1983), exchange rate appreciates in response to rising oil prices and depreciates with response to falling oil prices in oil exporting countries, while the opposite is expected to be the case in oil importing countries. According to Englama et al., (2010), a volatile exchange rate makes international trade and investments more difficult because it increases exchange rate risk. Exchange rate volatility tends to increase the risk and the uncertainty of external transactions and predisposes a country to exchange rate related risks (Jin, 2008).

According to Adedipe (2004), when Nigeria gained political independence in October 1960, agricultural production was the main stay of the economy, contributing about 70 percent of the Gross domestic product (GDP), also employing about seventy percent of the working population and responsible for about ninety percent of foreign government revenue. The initial period of post-independence till mid 1970s witnessed a fast advancement of industrialized capacity and output, as the contributions made by the manufacturing sector to GDP rose from 4.8 percent to 8.2 percent; this pattern changed as crude oil became important to the world economy. In the words of Englama et al., (2010), as crude oil became an export commodity in Nigeria in 1958, following the discovery of the first producible well in 1956; the contribution of oil to the federal government revenue rose from 26.3 percent in 1970 to 82.1 percent in 1974 and in 2008 constituted 83 percent of the federal government revenue, largely on account of increase in oil prices in the international market. The gigantic rise in oil revenue was caused by the Middle East war of 1973. It created extraordinary, surprising and unforeseen wealth for Nigeria and the naira appreciated as foreign exchange influxes offset outflows and Nigeria foreign reserves assets increased (Adedipe, 2004). The economy of Nigeria gradually became dependent on crude oil as productivity declined in other sectors (Englama et al., 2010).

Since the discovery of oil in commercial quantity, Nigeria has been largely a mono-product economy. The value of Nigeria's total export revenue in 2010 stood at US\$70,579 million, while income from petroleum exports of the total export revenue was US\$61,804 million representing about 87.6 percent. The absolute dependence of oil export revenue has accentuated the level of Nigeria economy vulnerability to sudden oil price movements.

Factors such as periods of favorable oil price shocks triggered by conflict in oil-producing countries of the world, rise in the demand for the commodity by the consuming nations due seasonality factors, trading positions etc; enhance Nigeria favorable terms of trade evidenced by her experiences of large current account surplus and exchange rate appreciation. On the converse, when crude oil prices are low, occasioned by factors such as low demand, seasonality factors, excess supply, the Nigeria experiences unfavorable terms of trade evidenced by budget deficit and slow economic growth (Englama, 2010). An example was a drop in the revenue from oil exports during the global financial crisis in 2009. According to OPEC statistical bulletin (2010/2011), 
oil export revenue dropped from US\$74,033 million in 2008 to US\$43,623 million in 2009 and the naira depreciated to N148.902 in 2009 from N118.546 in 2008.

This study attempts to examine the extent to which oil price influences exchange rate volatility in Nigeria. Oil price changes directly affects the inflow of foreign exchange into the country, therefore there is a need to investigate its impact on the naira exchange rate volatility; as crude oil is a key source of energy in Nigeria and in the world. Oil being an important part of the economy of Nigeria plays a strong role in influencing the economic and political fate of the country, crude oil has generated great wealth for Nigeria, but its effect on the growth of the Nigerian economy as regards returns and productivity is still questionable (Odularu 2007).

From the period of the oil boom of the 1970s till now, Nigeria has neglected her strong agriculture and light manufacturing bases in favor of an unhealthy dependence on crude oil. New oil wealth has led to a concurrent decline of other sectors in the economy and has fueled massive migration to cities and led to increasingly wide spread poverty especially in rural areas. As a result, Nigeria's job market has witnessed very high degree of unemployment, small wage and pitiable working environments (Adedipe, 2004 and Odularu 2007). Between 1970 to 2000 , Nigeria's poverty rate increased from 36 percent to just fewer than 70 percent and it is believed that oil revenue did not seem to add to the standard of living at this time but actually caused it to decline (Martin and Subramanian, 2003).

Oil price fluctuations have received important considerations for their presumed role on macroeconomic variables. Higher oil prices may reduce economic growth, generate stock exchange panics and produce inflation which eventually leads to monetary and financial instability. It will also lead to high interest rates and even a plunge into recession (Mckillop, 2004). Sharp increases in the international oil prices and the violet fluctuations of the exchange rate are generally regarded as the factors discouraging economic growth (Jin, 2008). A very good example is the period of the global financial crisis, the price of oil fell by about two thirds from its crest of $\$ 147.0$ per barrel in July 2008 to $\$ 41.4$ at end of December 2008. Before the crises, oil price was high, exchange rate was stable but with the dawn of the global financial crisis (GFC) oil price crashed and the exchange rate caved-in, depreciating by more than 20 per cent. Since oil price volatility directly affects the inflow of foreign exchange into the country, there is a need to investigate if it has direct impact on the Naira exchange rate volatility (Englama et al., 2010).

The oil market has been and will continue to be an ever changing arena. This is because oil is so vital to the world economy, it is present in everyone's daily lives and its market is truly global (El-badri, 2011). Thus, it is on this note that this study seeks to examine the effect of oil price on exchange rate volatility and its effects on the Nigerian economy, as well as suggest methods of minimizing the adverse effects it can produce on the economy as a whole.

The study adopts econometric technique in ascertaining the effect of oil price on exchange rate in Nigeria. The Johansen maximum likelihood test is used to determine the long run relationship between oil price and exchange rate volatility. The crude oil price and exchange rates are key research subjects, and both variables generate considerable impacts on macroeconomic conditions such as economic growth, international trade, inflation, and energy management. The relationships between the two have been studied, mainly for guidelines of interaction and causality. In past decades, changes in the price of crude oil have been shown to be a key factor in explaining movements of foreign exchange rates, particularly those measured against the U.S. dollar (Huang and Tseng, 2010).

While a considerable amount of studies have dealt with some aspect of the relationship between international oil price and exchange rate, a number of questions still spring to mind namely: Is there a significant link between oil prices and exchange rate determination in Nigeria? Do positive and negative shocks to oil prices volatility have symmetric effect on exchange rate volatility?

\section{Background facts}

Oil price movement and exchange rate volatility

Since the ending of the 1940s to the beginning 1970s the international oil price was very steady having only small changes. Then from the early 1970 to the early 1980s the price of oil increased beyond expectation with respect to the rise of OPEC and the disruption in the supply of crude oil. OPEC first exercised its oil controlling power during Yom Kippor War which started in 1973 by imposing an oil restriction on western countries as a result of U.S and the Europe support for Israel. Production of Oil was reduced by five million barrels a day, this cut back amounted to about seven percent of the world production and the price of oil increased 400 percent in six months.

From 1974 to 1978 crude oil prices were relatively stable ranging from $\$ 12$ to $\$ 14$ per barrel. Then between 1979 and 1980 during the Iranian revolution and Iraq war, the world oil production fell by 10 percent and caused the rise of crude oil price from $\$ 14$ to $\$ 35$ per barrel. Increasing oil prices forced leading consumers and firms to adopt a more conserve energy, people purchased cars that could manage fuel and organizations 
purchased machine that were more fuel efficient (Sharma 1998). Increased oil price also enlarged search and production by nations that were not members of OPEC. Beginning from 1982 to 1985 OPEC wanted to stabilize the price of oil through production of quotas, but safeguarding efforts, global economic meltdown and wrongful quotas produced by OPEC participant countries contributed to the plunging of oil prices beneath $\$ 10$ per barrel.

From the Mid-1980s the fluctuations in the price of oil has occurred more frequent than the past. OPEC has continually been trying to influence oil price to ensure its stability through allocation of production quotas to its member countries but has been unable to stabilize it; as OPEC share of the world oil production has fallen from 55 percent in 1976 to 42 percent today. Oil prices matter in the economy in various ways; changes in oil price directly affect transportation costs, heating bills and the prices of goods made with petroleum products. Oil price spikes induce greater uncertainty about the future, which affects households and firms spending and investments decisions. Also changes in oil prices leads to reallocations of labor and capital between energy intensive sectors of the economy and those that are non-energy intensive sector (Sill, 2009).

\subsection{Brief History of Oil in Nigeria}

The search for oil began in 1908 by a German company named Nigeria Bitumen Corporation, but there was no success until 1955 when oil was discovered in Oloibiri in Niger delta by shell-BP. Nigeria started exporting crude oil in 1958 but in major quantity in 1965, after the establishment of the bonny island on the coast of Atlantic and the pipeline to link the terminal. In 1970, as the Biafra war ends, there was a rise in world oil price and Nigeria benefited immensely from this rise. Nigeria became a member of the organization of petroleum exporting countries (OPEC) in 1971 and the Nigerian National Petroleum company (NNPC) which is a government owned and controlled company was founded in 1977. By the late sixties and early seventies, Nigeria had attained a production level of over 2 million barrels of crude oil a day. Although there was a drop in production of crude oil in the eighties due to economic down turn, by 2004 Nigeria bounced back producing 2.5 million barrels per day, but the Niger delta crisis and the global economy financial crises reduced Nigeria oil production and the world oil price.

The discovery of oil brought in the eastern and mid-eastern regions of Nigeria, this brought hope of a brighter future for Nigeria in terms of economic development as Nigeria became independent, but there were also grave consequences for the economy; as it fuelled already existing ethnic and political tension. The tension reached its peak with the civil war and reflected the impact and fate of the oil industry. Nigeria survived the war and was able to recover mainly from the huge revenue gained from oil in the 1970s. The Nigeria gained wholesomely from the nearly 36 months oil boom, the boom generates a lot of fund needed to meet all development need but the oil revenue which was supposed to be a blessing became a curse due to the corruption and the mismanagement of windfall gain from oil. The enormous impact of the oil shock on Nigeria grabbed the attention of scholars who tried to analyze the effect of oil price on economic growth in Nigeria. A set of radical oriented writers were interested in the nationalization that took place during the oil shock as well as the linkages between oil and an active foreign policy. Regarding the latter, the emphasis was on OPEC, Nigeria's strategic alliance formation within Africa, the vigorous efforts to establish the Economic Community of West African States (ECOWAS), and the country's attempts to use oil as a political weapon, especially in the liberation of South Africa from apartheid. Many people had hoped that Nigeria will become an industrial nation and a prosperous nation from the benefits of oil but they were greatly disappointed when a major financial crisis hit, which led to the restructuring of the economy (Odularu, 2007)

\section{Review of Related literature}

Diverse theoretical relationship between oil price and exchange rates have been established in literature (Beckmann and Czudaj 2012). Oil price fluctuations have received significant considerations for their perceived role in macroeconomic variables dynamism. The consequences of large increases in the oil price on macroeconomic variables have been of great concern among economist and policy makers as well as the general public, since two major oil price shocks hit the global economy in the 1970s (Sill 2009). The thought that exchange rate is the most difficult macroeconomic variable to model empirically is debatable. Many papers have suggested that oil price might have a significant influence on exchange rate. The proposition that oil price might be adequate enough to explain all the long run movements in real exchange rate appears to be new (Al-Ezzee, 2011)

Nigeria like other low income countries has adopted two main exchange rate regimes for the purpose of gaining balance both internally and externally. The purpose for this different practice is to maintain a stable exchange rate (Umar and Soliu 2009). A fluctuating real exchange rate stemming from volatile oil prices are damaging to non - oil sector, capital formation and per capita income (Serven and Solimano 1993 and Bagella 2006). The consequences of substantial misalignments of exchange rate can lead to shortage in output and extensive economic hardship. There is reasonably strong evidence that the alignment of exchange rate has a substantial influence on the rate of growth of per capita output in low income countries (Isard 2007). 
According to Trung and Vinh (2011) there are two reasons why macroeconomic variables should be affected by oil shocks. First, oil increase leads to lower aggregate demand given that income is redistributed between net oil import and export countries. Oil price spikes could alter economic activity because household income is spent more on energy consumption, and firms reduce the amount of crude oil it purchases which then leads to underutilization of the factors of production like labor and capital. Second, the supply side effects are related to the fact that crude oil is considered as the basic input to production process. A rise in oil price will lead to a decline in supply of oil due to the fact that a rise in cost of crude oil production will lead to a decline in potential output. Also, for various reasons known and unknown, oil price increases may lead to significant slowdown in economic growth. Five of the last seven United States of America recessions were preceded by significant increases in the price of oil (Sill, 2009). Likewise, a factor that has mitigated the rate of growth in some economies was not far from sudden sharp increases in the international price of oil (Jin, 2008).

Analysis of the impact of asymmetric shocks caused by exchange rate and oil price variability on economic growth has been a major concern of both academics and policy makers for a long time now (Aliyu 2009). According to Amano and Norden (1998) many researchers suggest that oil fluctuations has a significant consequence on economic activity and the effect differ for both oil exporting countries and oil importing countries. It benefits the oil exporting countries when the international oil price is high but it poses a problem for oil importing countries. According to Plante (2008), theoretically the immediate effect of positive oil price shocks is the increase in the cost of product for oil importing countries, this is likely to reduce output and the magnitude of this will depends on the demand curve for oil. Higher oil prices lower disposable income which then leads to a decrease in consumption. Once the increase in oil price is believed to be permanent, private investments will decrease. But if the shocks are perceived as transitory, oil is used less in production and the productivity of labor and capital will decline and potential output will fall. Similarly, Patti and Ratti (2007) shows that oil price increases have a greater influence on the economy than a decrease in oil price.

Also, Rickne (2009) posits that political and legal institutions affect the extent to which the real exchange rate of oil exporting countries is affected by international oil price shocks. In a theoretical model succinctly espoused by literature, strong institutions protect real exchange rate from oil price volatility by generating a smooth pattern of fiscal spending over the price cycle. Empirical analysis carried out on 33 oil exporting countries show that countries with high bureaucratic quality, and strong and impartial legal system have real exchange rate that are affected less by oil price. Also according to Mordi and Adebiyi (2010) the asymmetric effect of oil price changes on economic activity is different for both oil price increase and oil price decrease. Empirical research suggesting that oil price serves as a major determinant of real exchange rate has yielded somewhat puzzling results for oil exporting countries (Rickne, 2009).

Korhonen and juurikkala (2007) showed that increasing crude oil prices cause a real exchange rate appreciation in oil exporting countries and this is not shocking, since they earn a significant amount from oil exportation. There is also a significant relationship between real oil prices and real exchange rates for oil importing countries; evidence has been seen for Spain (Camarero and Tamant 2002). A study carried out on the Russian economy by Spatafora and Stavrev (2003) confirm the sensitivity of Russia's equilibrium real exchange rate to long run oil prices. Likewise, Suseeva (2010) verified a long run positive relationship between the real oil price and the real bilateral exchange rate against Euro in Russia. Lizardo and Mollick (2010) provided proof that between the year 1970s to 2008, movements in the value of the U.S dollar against major currencies was significantly explained by oil prices. They found that when oil prices increases, currencies of oil importers such as china suffer depreciation. On the other hand, in net-oil exporters such as Canada, Mexico and Russia, increase in oil prices leads to a noteworthy depreciation of the US dollar. But, Akram (2004) finds strong evidence of no linear relationship between oil prices and the Norwegian exchange rates.

Using quarterly data from 1974 to 1992 comparing the United States of America to four different countries (Germany, United Kingdom, Japan and Canada), Clarida and Gali (1999) estimate the share of exchange rate fluctuations that is due to the different shocks in oil and found that more than 50 precent of the variance of real exchange rate changes over all the horizons was caused by real oil shocks. Amano and Norden (1998) using data on real effective exchange rates for Germany, Japan and United States of America discovered that real oil price is the most important factor in determining real exchange rates in the long run.

In the same manner, if the productivity of tradable relative to non-tradable is larger in other countries, it could lead to the appreciation of the real exchange rate. This is the Balassa-Samuelson hypothesis formulated by Balassa (1964) and Samuelson (1964). According to Coudert (2004), the Balassa-Samuelson effect is the mechanism by which an appreciation of the real exchange rate occurs owing to changes in relative productivity. We use the real oil price as a representation of the terms of trade and examine the influence of oil price fluctuations and productivity differentials on the real exchange rate given that oil price is the main export good driving the terms of trade in oil exporting countries. In practice, the price of the main exported good is often used as an indicator of the terms of trade (Sossounov and Ushakov, 2009). 
Using a panel of 16 developing countries, Choudhri and Khan (2004) provided strong evidence of the workings of the Balassa Samuelson effects. Coudert (2004) survey provided evidence that the trend appreciation in the real exchange rate observed in countries of central and eastern Europe during the early 2000 stemmed, in fact, from the Balassa effect. The study concluded that even though other factors were just as responsible, the estimated Balassa effect goes some way in explaining the real appreciation.

Kutan and Wyzan (2005) using an extended version of the Balassa-Samuelson model finds evidence that changes in oil prices had a significant effect on the real exchange rate during 1996 to 2003 and that the Balassa- Samuelson working through productivity changes may be present though its economic significance may not be large. Cashin et al., (2004) carried out a study on over 50 commodities exporting developing countries and found a long-run relationship between exchange rate and the exported commodity's price in one third of their sample. In a recent study, Ozsoz and Akinkunmi (2011) also demonstrated the positive effects of international oil prices on Nigeria's exchange rate.

Using monthly panel of G7 countries, Chen and Chen (2007) investigate the long run relationship between real oil price and real exchange rates and found that real oil prices is a dominant cause of real exchange rate movements. Olomola (2006) investigated the impact of oil price shocks on aggregate economic activity in Nigeria using quarterly data from 1970 to 2003. He discovered that contrary to previous empirical findings, oil price shocks do not affect output and inflation in Nigeria significantly. However oil price shocks were found to significantly influence the exchange rate.

In Bahrain Johansen co-integration test is used to examine the co-integrating relationship among the real GDP, real effect exchange rate and real oil price of a country. Real GDP of Bahrain is more elastic to changes in international oil prices than real exchange rate (Al-zee, 2011). Research conducted on Vietnam from the period of 1995 to 2009 using the vector autoregressive model (VAR) produce results that suggest that both oil prices and the real effective exchange rates have strong significant impact on economic activity.

Habib and Kalamova (2007) investigate the effect of oil price on the real exchange rate of three countries namely; Norway, Saudi Arabia and Russia. In case of Russia, a positive long run relationship was found between oil price and exchange rate and no impact of oil price on exchange rate was found for Norway and Saudi Arabia. Aliyu (2009) and Rickne (2009) believe that this is due to lack of strong institutions and total dependency on oil exports. Aliyu (2009) recommends larger divergence of the economy through the investment in top prolific sector to reduce the adverse effect of oil price shocks and the exchange rate volatility.

\section{Model Specification and Data Sources}

In line with the theoretical model built by Adedipe (2005) and Adeniyi (2011), the study adopted a GARCH model theory which makes the exchange rate dependent on the oil price. The model is represented as follow:

$$
\begin{aligned}
& \text { Vol_EXR }=f(\text { oilp }, e r, \text { int }) \\
& \text { Vol_EXR }=\beta_{0} \text { oilp }^{\beta_{1}} \mathrm{er}^{\beta_{2}} \text { int }^{\beta_{3}} \\
& \text { logVol_EXR } R_{t}=\beta_{0}+\beta_{1} \operatorname{logoilp}_{t}+\beta_{2} \operatorname{loger}_{t}+\beta_{3} \operatorname{logint}_{t}+\mu_{t}
\end{aligned}
$$

Where vol_exr $r_{t}$ is the volatility of exchange rate generated by obtaining the standard deviation of percentage change in exchange rate, oil $p_{t}$ is oil price, $e r_{t}$ is official exchange rate, $i n t_{t}$ is interest rate (lending)

\begin{tabular}{|c|c|c|}
\hline Variable & Description/ Measurements & Data Sources \\
\hline oil price (oilp) & $\begin{array}{l}\text { The price of crude oil is stated in us dollars. Oil price is } \\
\text { the price at which oil is sold per barrel each day in the } \\
\text { international oil market. it is measured in us dollars }\end{array}$ & $\begin{array}{l}\text { BP statistical review of } \\
\text { energy } 2012\end{array}$ \\
\hline external reserves (er) & $\begin{array}{l}\text { This is the amount of revenue saved by country from } \\
\text { trading with other nations. it is measured in us dollars } \\
\text { millions }\end{array}$ & $\begin{array}{l}\text { CBN statistical bulletin } \\
2011\end{array}$ \\
\hline interest rate (int) & $\begin{array}{l}\text { It is the charge for borrowing money, usually measured } \\
\text { as the percentage ratio between the sum payable to the } \\
\text { lender and the amount borrowed, at an annual rate. The } \\
\text { amount of money contractually promised at certain } \\
\text { specified future dates as a proportion of the principal } \\
\text { borrowed. }\end{array}$ & $\begin{array}{l}\text { CBN statistical bulletin } \\
2011\end{array}$ \\
\hline exchange rate (vol_exr) & $\begin{array}{l}\text { It is the price of a country currency expressed in terms } \\
\text { of one unit of another country's currency. It is measure } \\
\text { as the exchange rate of the naira to the dollar. }\end{array}$ & $\begin{array}{l}\text { Figures for exchange rate } \\
\text { derived from CBN } \\
\text { statistical bulletin. }\end{array}$ \\
\hline
\end{tabular}
and $\mu_{t}$ is the stochastic random term.

Table 1: Data Sources and Descriptions

Source: compiled by authors 


\subsection{Technique of estimation}

The econometric technique adopted is based on the Johansen maximum likelihood estimation procedure and the vector error correction model (VECM); while the former enables to determine cointegration rank of our model, the later helps to ascertain possibility of error correction as the model approaches it long run equilibrium path. The choice of a cointegration technique over the ordinary least square techniques lies on the following; i. most time series data are not stationary, implying that the assumption of a constant mean, a constant variance and a constant auto variance for every successive lag is mostly violated, so the use of the OLS method of estimation could only yield a spurious results. ii. Cointegration approach is a convenient approach for the estimation of long run parameters. iii. The cointegration approach provides a direct test of the economic theory and enables utilization of the estimated long run parameters into the estimation of the short run disequilibrium relationships. iii. The traditional approach is criticized for ignoring the problems caused by the presence of unit roots variables in the data generating process. However both unit root and cointegration have important implications for the specification and estimation of dynamic models

\subsection{The Test for Stationarity (Unit Root)}

The unit root test precede the co-integration analysis due to the fact that majority of economic data do exhibit a non-stationary trend which could lead to misleading results. A unit root test tests whether time series variable is non-stationary using autoregressive model. A common test and valid for large samples is the Augmented dickey fuller (ADF) and Phillips Perron test. They are used to determine the order of integration of a variable. The test states that if a particular series say $\mathrm{Y}$ has to be differenced $\mathrm{n}$ times (number of times, $1,2,3 \ldots$ n) before it becomes stationary then $Y$ is said to be integrated of order n (it is written as I(n)). If the series is stationary at level, it is said to be integrated to order $0(\mathrm{I}(0))$, that is there is no unit root. If a variable is differentiated once in order for it to be stationary, it is said to be integrated to order 1 that is I(1).

The test statistics of the estimated coefficient of $Y$ is then used to test the null hypothesis that the series is non-stationary (has unit root). If the absolute value of the test statistics is higher than the absolute value of the critical value (which could be at 1,5 , or 10 percent) then the series is said to be stationary, therefore we reject the null hypothesis, otherwise it has to be differentiated until it becomes stationary.

\subsection{Johansen Test for Co-integration}

Co-integration is based on the ideology that there exists long run co-movement between trended economic data, so that there is a common equilibrium relation that the time series have a tendency to revert to, therefore even if certain time series are non-stationary, a linear combination of them may exist that is stationary. A lot of economic series behave like I(1) processes, that is, they seem to drift swiftly but not too largely apart.

Johansen test named after Soren Johansen is a procedure for testing cointegration of I(1) time series. This test permits more than one co integrating relationships, so it's more applicable than the Engle-Granger test which is OLS based. There are two types of Johansen test, namely; Trace and Maximal Eigen-value statistics, both are commonly use to ascertain the number of cointegration rank or in determining the number of cointegrating vectors. Both tests might not always indicate the same number of cointegrating vectors. A cointegrating vector is attained when obtained critical values are more the values for trace and maximum Eigenvalue statistics.

\subsection{The Vector Error Correction Model}

This is based on vector autogressive framework; where an error correction term is incorporated into the model. The reason for the error correction term is the same as with the standard error correction model, it measures any movements away from the long run equilibrium and measures the speed of adjustment of the short run dynamics to the long run equilibrium time path. The coefficient is expected to be negatively signed, statistical significant and lie between zero and one.

\subsection{Test for Unit Root}

\section{Econometrics Analysis}

Unit root test is carried out to determine if the variables are stationary or otherwise; and if stationary, to determine their order of integration (i.e. number of times they are to be differenced to achieve stationarity). In standard econometric analysis using a time series data, it is expedient to conduct a stationary test; this is due to the fact that most time series data are non-stationary. The unit root tests were conducted using the Augmented Dickey Fuller test (ADF) and the Phillips Perron (PP) test; these two were conducted for the time series employed in the study. The Augmented Dickey Fuller (ADF) result and the Phillips Perron (PP) test show that all the variables (LEXRV, LOILP, LER AND LINT) are all integrated series of order I (1). 
Table 2: Augmented Dickey Fuller (ADF) and Phillips Perron (PP) test for unit root

\begin{tabular}{|c|c|c|c|c|c|c|}
\hline \multirow[t]{2}{*}{ Variable } & \multicolumn{3}{|c|}{ Augumted Dickey fuller test(ADF) } & \multicolumn{2}{|c|}{ Phillips Perron (PP) } & \multirow[b]{2}{*}{ OI } \\
\hline & Level & $\begin{array}{l}\text { First } \\
\text { difference }\end{array}$ & OI & Level & First Difference & \\
\hline Lexrv & -1.062207 & $-18.62853^{*}$ & $\mathrm{I}(1)$ & -0.529109 & $-16.39442 *$ & $\mathrm{I}(1)$ \\
\hline Loilp & -2.137543 & $-6.058508^{*}$ & I(1) & -2.137724 & $-6.058478^{*}$ & $\mathrm{I}(1)$ \\
\hline Ler & -2.207279 & $-6.719037^{*}$ & $\mathrm{I}(1)$ & -2.166444 & $-7.124260 *$ & I(1) \\
\hline Lint & -2.048322 & $-9.138885^{*}$ & I(1) & -1.878074 & $-9.863937 *$ & I(1) \\
\hline
\end{tabular}

$*, * *, * * *$ indicate statistical significance at $1 \%, 5 \%$, and $10 \%$ respectively. OI signifies order of integration Source: Computed by using E-views 7.

Table 2 shows that all the variables are not stationary at level. This can be seen by comparing the observed values (in absolute terms) of the Augmented Dickey fuller (ADF) test and Phillips Perron test statistics with the critical value (also in absolute terms) at 1 percent, 5 percent and 10 percent level of significance. As a result of this, the variables were differenced once and all the variables became stationary at first difference, that is, they are integrated of the same order I(1)

\subsection{Johansen Maximum Likelihood Test of Co-integration}

The major aim of this test is to ascertain whether a linear combination of the integrated variable is becomes stationary over the long-run, if this hold sway, then it means cointegration exists among the variables, this further implies that there exist a long run relationship among the variables. The Johansen cointegration test commenced with the test for the number of cointegrating relations or rank using Johansen's maximum Eigen value and the trace test. The results are shown below:

Table 3: Johansen Cointegration

\begin{tabular}{lllll}
\hline No. of co-integrating equation & \multicolumn{2}{c}{ Trace Statistic } & \multicolumn{3}{c}{ Maximum Eigen value } \\
\hline & Statistic & 5 percent CV & Statistic & 5 percent CV \\
None & 79.88171 & 63.87610 & 40.88306 & 32.11832 \\
At most 1 & $38.99865^{*}$ & $42.91525^{*}$ & $18.28741^{*}$ & $25.82321^{*}$ \\
At most 2 & 20.71124 & 25.87211 & 14.19844 & 19.38704 \\
At most 3 & 6.512805 & 12.51798 & 6.512805 & 12.51798 \\
\hline
\end{tabular}

Source: Computed by using E-views 7.

The two tests produced the same result. The trace test rejected the null hypothesis $\left(\mathrm{H}_{0}\right)$ that there is no co-integrating relationship between the variables and the test based on the maximum Eigen value also rejected the null hypothesis. They both indicate evidence supporting one co-integrating equation at the 5 percent level of significance. The result of the co-integration test showed that LEXRV, LOILP, LER AND LINT have equilibrium condition which keeps them in proportion to each other in the long run. The exactly identifying estimates of the Johansen Maximum likelihood estimates show the co-integrating coefficients normalized to LEXRV as below. They are very useful in understanding the long run relationships among co-integrating variables.

Table 4: Normalized Co-integrating coefficients

\begin{tabular}{lllll}
\hline Variables & LEXRV & LOILP & LER & LINT \\
\hline Coefficients & 1.000000 & 2.860249 & -0.531970 & -0.532029 \\
Standard Error & & $(0.3 .1751)$ & $(0.29149)$ & $(0.91854)$ \\
& & 9.0083 & -1.70905 & 0.0012114 \\
\hline
\end{tabular}

Source: Computed by using E-views 7.

Since our model was expressed in logarithm form, the co-efficient estimates can be interpreted in terms of long run elasticity and the t-statistics is used to determine the statistical significance of each variable. Based on the rule of thumb, a variable is said to be statistically significant if the absolute value of its t-statistic is approximately 2 or above.

The major relationship of interest is centered on direction of behavior that exists between oil price and exchange rate volatility in Nigeria. From the table 4, oil price is elastic in relation to exchange rate volatility, implying that in the long run, a change in oil price will cause a more than proportionate change in exchange rate volatility and the significance of its t-statistic shows that oil price exerts an elastic significant fluctuation on exchange rate volatility in Nigeria; while interest rate does not significant contribute to dynamism in exchange rate volatility. We can rightly deduce from our result that oil price movements have contributed enormously to the exchange rate volatility in Nigeria, our result is consistent to study conducted by Kutan and Wyzan (2005) 
and Ozsoz and Akinkunmi (2011) who all demonstrated that changes in oil price had a significant effect on real exchange rate for 50 commodity exporting countries and Nigeria respectively.

\subsection{The Vector Error Correction Model}

The ECM coefficient is known as the speed of adjustment factor, it tells how fast the system adjusts to restore equilibrium. It captures the reconciliation of the variables over time from the position of disequilibrium to the period of equilibrium. The result of the vector correction model (VECM) is shown on table 5; the basic criteria for analyzing VECM are: 1 . The VECM must lie between 0 and $1 ; 2$. it must be negative for it to be meaningful. If it's positive there is no error correction and therefore diverges; and 3. the t-statistic must be significant.

Table 5: Vector Error Correction Model

\begin{tabular}{lll}
\hline Variables & ECM(-1) & T-statistic \\
\hline D(LEXRV) & -0.633566 & -10.2559 \\
D(LOILP) & -0.037631 & -1.11319 \\
D(LER) & -0.011029 & -0.13882 \\
D(LINT) & -0.012318 & -0.60156 \\
\hline
\end{tabular}

Source: Computed by using E-views 7.

The speed of adjustment co-efficient for LEXRV is -0.633566 . The VECM is correctly signed and in terms of magnitude it lies between 0 and 1 . Satisfying these criteria signifies that the model has the capacity to correct errors generated in the immediate periods at it approaches its long run equilibrium path. Precisely the error correction model in this equation means that about 63.35 percent of errors generated between each period are correlated in subsequent periods. Since errors are short lived in our model, it implies that the long run relationship obtained is sustainable and our result is reliable.

\section{Recommendation and Conclusion}

This research study seeks to ascertain whether oil price has a significant influence on exchange rate volatility in Nigeria over the periods 1970 -2010 using the Johansen and vector error correction approach. It also looks at other factors that can influence exchange rate in Nigeria like external reserves and interest rate. In the model exchange rate volatility was the dependent variable and the independent variables were oil price, external reserves and interest rate. After the review of relevant literature and the necessary empirical analyses it was observed that a proportionate change in oil price will lead to a more than proportionate change in exchange rate volatility.

In the words of Jin (2008), Exchange rate volatility increases the risk and uncertainty of external transactions and predisposes a country to exchange rate related risks. For the purpose of this research work, the following strategies are suggested to reduce exchange rate volatility in Nigeria. Our study was consistent with Adeoye and Atanda (2005) which showed that there is presence and persistency of volatility shocks in the nominal and real exchange rates for naira vis-à-vis U.S dollar in Nigeria between 1986 and 2008. This implies that the conservative monetary management policies put in place for stabilizing the exchange rate of a unit U.S dollar to naira over the years has been ineffective. There is a need for FOREX management measures particularly in terms of meeting the high demand for foreign currency which characterized the performance, trade balance and overall economic performance in Nigeria. There is also the need for sound monetary policy to attain stability in the exchange rate. Likewise, assuming government expenditure is closely aligned to revenue from natural resource, the revenue will become more unpredictable, which ultimately cause expenditure instability, and in turn cause instability in the real exchange rate. A vast body of empirical study records the terrible effect of economic volatility on investment and growth. Therefore Nigeria government should look for new ways to diversify the economy into, from dependence on oil and explore other sectors like manufacturing sector and agricultural sector to reduce the effect of uncertainties in the economy. Finally, higher revenue gotten from increases in oil prices should be invested into different areas of the economy as the exchange rate of a country is influenced by prevalent economic conditions.

\section{References}

[1]. Adedipe, B. (2004).The Impact of Oil on Nigeria's Economic Policy formulation. Maximizing Pro-poor Growth: Regenerating the Socio-economic Database, organized by Overseas Development Institute in collaboration with the Nigerian Economic Summit Group, 16th -17thJune 2004

[2]. Adeniyi, O.A. (2011). Oil price shocks and Exchange rate dynamics in oil exporting countries: what is the Nigerian experience? Being a paper presented at the Fourth NAEE/IAEE international Conference

[3]. Adeniyi, O., Omisakan, O., Yaqub, J. \& Oyinlola, A. (2012). Oil price-Exchange rate Nexus in Nigeria: Further Evidence from an oil exporting country.

[4]. Adeoye, B. W. \& Atanda, A.A. (2005). Exchnage rate Volatility in Nigeria consistency, Persistency and Severity Analyses, CBN Journal of Applied Statistics Vol.2 No.2 
[5]. Akram, Q. F. (2004).Oil prices and exchange rates: Norwegian evidence, The Econometrics Journal, 7, pp. 476-504

[6]. AL-Ezzee, I. (2011). Real influences of Real Exchange rate and Oil price changes on the growth of real GDP: Case of Bahrain, International Conference of Management and service science IPEDR vol.8

[7]. Aliyu, S., \& Usman, R. (2009a). Impact of Oil Price Shock and Exchange Rate Volatility on Economic Growth in Nigeria: An Empirical Investigation, Journal of International StudiesIssue 11, pp4-15

[8]. Amano, R., \&Norden, S. (1995). Exchange Rate and Oil Price, Bank of Canada working Paper no.95-8.

[9]. Bagella, M., Becchetti, L., Hasan,I. (2006). Real effective exchange rate volatility and growth: A framework to measure advantages of flexibility vs. costs of volatility, J. Bank Finance 30 (2006) 1149-169.

[10]. Beckmann, J., \& Czudaj, R. (2012) Oil price and U.s dollar exchange rate dynamics

[11]. Bollerslev, T., (1986)Generalised Autoregressive Conditional Heteroskedasticity. Journal of Econometrics31, 307-327

[12]. Brahmbhatt, M., Canuto, O., \& Vostroknutova, E. (2010). Dealing With Dutch disease, poverty and economic management network (PREM), No. 16,June, pp4

[13]. Cashin, P., Céspedes, L. F; \& Sahay, R. (2004). Commodity currencies and the real exchange rate, Journal of Development Economics, Vol. 75, 239-268.

[14]. Chen, H., \& Chen, C., (2007). Oil Prices and Real Exchange Rate, Energy Economics,29, 390- 404

[15]. Dawson, J. (2010). The effect of Oil price on Exchange rate in Nigeria: The case of Dominican Republic.

[16]. Englama, A., Duke, O. O., Ogunleye, S., \& Isma F. U. (2010). Oil Price and Exchange rate Volatility in Nigeria: An Empirical observation.

[17]. Engle, R. F (1982). Autoregressive Conditiional Heteroscedasticity with Estimates of the Variance of United Kingdom Inflation. Econometrica, 50, pp987-1007.

[18]. Habib, M. M;\&Kalamova, M. (2007). Are There Oil Currencies? The Real Exchange Rate of Oil Exporting Countries, In European Central Bank working Paper 839.

[19]. Isard, P. (2007). Equilibrium Exchange Rates: Assessment Methodologies IMF Working paper WP/07/296

[20]. Jin, G., (2008). The Impact of Oil Price Shock and Exchange Rate Volatility on Economic Growth: A comparative analysis for Russia, Japan, and China. Research Journal of International Studies, Issue 8, pp98-111

[21]. Koranchelian, T., (2005): The Equilibrium Real Exchange Rate in a Commodity Exporting Country: Algeria ${ }^{e e}$ Experience, IMF Working Paper 05/135

[22]. Korhonen, I. and T. Juurikkala (2007). Equilibrium exchange rates in oil-dependent Countries, BOFIT Discussion Papers 8/2007, Bank of Finland, Institute for Economies in Transition

[23]. Krugman, P., (1983).Oil shocks and exchange rate dynamics In Exchange Rates and International Macroeconomics, University of Chicago Press

[24]. McKillop, A. (2004). Oil Prices, Economic Growth and World Oil Demand, Middle East Economic Survey, vol. xlvii No 35.

[25]. Mordi, C. N. O. (2006). Challenges of Exchange Rate Volatility in Economic Management in Nigeria.Central Bank of Nigeria Bullion, 30(3).

[26]. Muhammad, Z., Suleiman, H., \& Kouhy, R. (2010). Exploring Oil Price-Exchange rate nexus forNigeria.FIW working paper No71

[27]. Nelson, D. B. (1991). Conditional heteroscedasticity in asset returns: a new approach. Econometrica, 59, pp347-370.

[28]. Obadan, M. I. (2006). Overview of Exchange rate Management in Nigeria from 1986 to Date.CBN statistical bulletin, Vol, No. 3 (July-September)

[29]. Odularu, G.O. (2007). Crude Oil and Nigeria Economic Performance

[30]. Ojebiyi, A. \& Wilson D. O. (2011). Exchange rate Volatility: An analysis of the relationship between Naira, Oil price and US dollars

[31]. Olomola, A., (2006). Oil Price Shock and Aggregate Economic Activity in Nigeria, African Economic and Business Review Vol.4: 2, ISSN 1109-5609

[32]. Olomola, P.A., Adejumo A.V. (2006). Oil Price Shocks and Macroeconomic Activities in Nigeria, International Research Journal of Finance and Economics, 3, 28-34.

[33]. Plante, M. (2008). Oil price shocks and Exchange rate management: the implications of consumer durables for the small open economy

[34]. Ricken J. (2009). Oil Price and Real Exchange Rate Volatility in Oil-Exporting Economies: The Role of Governance, IFN Working paper No. 810, Research

[35]. Sanusi, J.(2004). Nigeria's Exchange rate mechanism: The current Experience. Being aPaper presented at Nigerian- British Chamber of commerce.

[36]. Schnabl, G. (2007). Exchange Rate Volatility and Growth in Small Open Economies at the EMU Periphery, Working Paper Series, No. 773

[37]. Serven, L. \& Solimano A. (1993). Striving for Growth after adjustment: The Role of Capital Formation.

[38]. Spatafora, N., \&Stavrev, E. (2003). The Equilibrium Real Exchange Rate in a Commodity xporting Country: The Case of Russia, IMF Working Paper 93

[39]. Söderlind, P. (2011). Lecture Notes in Financial Econometrics In (MBF,MSc course at UNISG).University of St.Gallen. Switzerland.

[40]. Trung, V. \& Vinh, N., (2011). The Impact of Oil prices, Real Effective exchange rate and Inflation on Economic Activity: Novel Evidence for Vietnan

[41]. Umar, A. \& Soliu, U. The Foreign Exchange rates in Nigeria: Convergence and Divergence

[42]. Wang, P. (2003). Financial Econometrics: Methods and Models London: Routledge advanced texts in economics and finance.

[43]. Xavier, S. \&Subramanian, A. (2003). Addressing the Natural Resource Curse: An Illustration from Nigeria, NBER Working Paper 9804, Cambridge, Mass 